\title{
HARMONISASI NORMA HUKUM BAGI PERLINDUNGAN HAK KEPERDATAAN ANAK LUAR KAWIN DALAM SISTEM HUKUM INDONESIA
}

\author{
Bernadeta Resti Nurhayati \\ Universitas Katolik Soegijapranata Semarang \\ Email: bernadeta_resti@yahoo.com
}

\begin{abstract}
Abstrak
Masyarakat dan hukum telah lama melakukan diskriminasi terhadap anak luar kawin. Hal ini menyebabkan anak luar kawin mendapatkan stigma negatif dalam kehidupannya sehari-hari. Masyarakat menyebutnya dengan berbagai istilah seperti: "anak haram", "haram jadah", "anak kowar", "anak astral" dan sebagainya. Sampai saat ini hukum Indonesia membedakan status, kedudukan serta hak-hak anak luar kawin. Persoalan yang mendesak untuk segera diselesaikan adalah ketidakharmonisan dalam norma hukum tertulis yang mengatur tentang perlindungan anak luar kawin. Tujuan penelitian adalah untuk melakukan evaluasi dan harmonisasi atas norma hukum yang ada dalam bidang perlindungan hak keperdataan anak luar kawin. Harmonisasi atas norma hukum ini dengan mendasarkan pada praktek perlindungan hukum, doktrin, serta norma-norma tertulis yang berkaitan langsung dengan perlindungan anak luar kawin di Indonesia. Penelitian ini merupakan pelengkap disertasi. Pada penelitian ini dilakukan: inventarisasi norma hukum positif di bidang status dan kedudukan anak luar kawin, praktek hukum berkaitan dengan perlindungan bagi anak luar kawin serta teori hukum yang relevan untuk melihat kemungkinan perlindungan hak anak. Dalam penelitian ini akan dilakukan pemetaan terhadap norma dan lembaga untuk mengetahui bagian-bagian yang bertentangan/tidak berkesesuaian satu sama lain, sebagai dasar untuk menyusun harmonisasi peraturan perundang-undangan di bidang status serta kedudukan anak luar kawin. Dari harmonisasi ini diharapkan akan ditemukan norma yang perlu direvisi serta formula rumusan norma yang memberikan perlindungan terhadap hak keperdataan bagi anak luar kawin di Indonesia. Luaran yang dihasilkan berupa: draft disertasi yang telah disetujui promotor, publikasi ilmiah internasional bereputasi, publikasi nasional terakreditasi, pemakalah pertemuan nasional dan internasional, serta luaran tambahan berupa draft buku referensi.
\end{abstract}

Kata kunci : harmonisasi perundang-undangan, perlindungan hukum, anak luar kawin.

Abstract

Communities and laws have long discriminated against children outside of marriage. This causes out of wedlock children to get a negative stigma in their daily lives. People call it with various terms such as: "anak haram", "haram jadah", 


\begin{abstract}
"anak kowar", "anak astral" and so on. Until now Indonesian law distinguishes the status, position and rights of children out of wedlock. An urgent issue to be resolved is disharmony in written legal norms that regulate the protection of children outside of marriage. The research objective is to evaluate and harmonize the legal norms that exist in the field of protection of civil rights of non-married children. Harmonization of these legal norms is based on the practice of legal protection, doctrine, and written norms that are directly related to the protection of extramarital children in Indonesia. This research is a complement to the dissertation. In this research, an inventory of positive legal norms in the field of status and position of out-of-child children, legal practices relating to the protection of children outside of marriage and the relevant legal theory to see the possibility of protection of children's rights. In this research, mapping of norms and institutions will be conducted to find out the parts that are conflicting / incompatible with each other, as a basis for formulating harmonization of laws and regulations in the field of status and position of children outside of marriage. From this harmonization, it is expected that norms that need to be revised will be found and formulas for norms that provide protection for civil rights for married children in Indonesia. Outputs are in the form of: draft dissertations that have been approved by promoters, reputable international scientific publications, accredited national publications, speakers of national and international meetings, and additional outputs in the form of draft reference books.
\end{abstract}

Keywords: harmonization of legislation, legal protection, extramarital children.

\title{
1. Pendahuluan
}

Di Indonesia, persoalan status perdata anak yang lahir di luar perkawinan menyeruak sejak kasus gugatan hak keperdataan anak MM yang menikah siri dengan alm. Moerdiono, mantan Menteri Sekretaris Negara pada era pemerintahan presiden Soeharto. Perjalanan panjang perjuangan MM memperjuangkan hak keperdataan anaknya menjadi catatan sejarah hukum di Indonesia. Gugatan peninjauan Undang-Undang Nomor 1 Tahun 1974 tentang Perkawinan (UUP) dikabulkan sebagian oleh Mahkamah Konstitusi, terutama terkait dengan bunyi Pasal 43 ayat (1) UUP yang kemudian harus dibaca menjadi:

"Anak yang dilahirkan di luar perkawinan mempunyai hubungan perdata dengan ibunya dan keluarga ibunya serta dengan laki-laki sebagai ayahnya yang dapat dibuktikan berdasarkan ilmu pengetahuan dan teknologi dan/atau alat bukti lain menurut hukum mempunyai hubungan darah, termasuk hubungan perdata dengan keluarga ayahnya".

Meskipun telah ada putusan Mahkamah Konstusi Nomor 46/PUU-VIII/2010, namun untuk mendapatkan hak keperdataan atau sekurang-kurangnya pengakuan dari ayah biologisnya tetap tidaklah mudah.

Undang-undang dan doktrin hukum membedakan status anak menjadi anak sah dan ALK (dalam tulisan ini untuk selanjutnya disebut ALK). Pasal 42 UUP menyebutkan: "Anak yang sah adalah anak yang dilahirkan di dalam atau sebagai akibat perkawinan yang sah". Dengan demikian anak yang dilahirkan tidak di 
dalam, atau bukan sebagai akibat perkawinan yang sah, dikategorikan sebagai "anak luar kawin". 1

Perbedaan status anak, berakibat pada hubungan hukum anak dengan orangtuanya. Antara anak dengan ibunya, secara otomatis anak memiliki hubungan keperdataan. Tidak demikian halnya dengan bapak biologisnya. Tiadanya hubungan keperdataan antara anak dengan bapak biologisnya, menyebabkan si anak tidak berhak mendapatkan hak alimentasi, hak atas pemeliharaan, hak untuk memakai nama keluarga si bapak dan hak mewaris. Bapak biologis harus melakukan "pengakuan terhadap si anak" agar timbul hak keperdataan pada si anak. Atau dalam hal bapak biologis menikah dengan ibunya, maka harus dilakukan "pengesahan anak".

Namun dalam hukum Indonesia, meskipun telah ada putusan MK No. 046/PUU-VIII/2010, tidak mudah bagi ALK untuk mendapatkan status keperdataan dengan ayahnya. Bahkan UU No. 24 tahun 2013 tentang Perubahan UU No. 23 tahun 2006 tentang Administrasi dan Kependudukan menghilangkan harapan bagi ALK yang lahir sebelum perkawinan sah agama kedua orangtuanya tidak dapat diakui, sedangkan mereka tidak pernah meminta untuk dilahirkan di luar perkawinan.

Hal ini menimbulkan pertentangan antara doktrin/ilmu hukum perdata dengan hukum perlindungan anak, karena pada dasarnya Deklarasi Universal Hak-hak Asasi Manusia (DUHAM) tidak membeda-bedakan manusia siapapun dia. Semua orang sama di depan hukum dan berhak atas perlindungan hukum yang sama tanpa diskriminasi yang bertentangan dengan Deklarasi ini, dan terhadap segala hasutan yang mengarah pada diskriminasi semacam ini. Hal inilah yang membuat persoalan hak keperdataan ALK menarik untuk dikaji, karena sebagai anak-anak mereka membutuhkan perlindungan hukum untuk dapat tumbuh kembang secara sempurna.

Berdasarkan uraian pada latar belakang permasalahan tersebut di atas, maka dirumuskan permasalahan utama dalam penelitian ini adalah :

1. Bagaimanakah norma-norma hukum eksisting yang memberikan perlindungan hukum bagi ALK di Indonesia?

2. Bagaimanakah seharusnya norma-norma hukum itu secara harmonis dapat memberikan perlindungan hukum terhadap ALK?

\section{Kajian Literatur}

a. Perkawinan dalam Sitem Hukum Indonesia

Dalam hukum positif Indonesia, perkawinan diatur dalam UU Nomor 1 tahun 1974 tentang Perkawinan (UUP). UUP memberikan definisi perkawinan dalam Pasal 1 yang menyebutkan: "Perkawinan adalah ikatan lahir batin antara seorang pria dengan seorang wanita sebagai suami isteri dengan tujuan membentuk keluarga (rumah tangga) yang bahagia dan kekal berdasarkan Ketuhanan Yang Maha Esa.”

Abdulkadir Muhammad menyebutkan bahwa salah satu dilakukan pembedaan antara anak sah dan anak luar kawin adalah untuk mengurangi kemungkinan terjadinya kelahiran sebelum dilangsungkannya perkawinan, dan juga ada hubungannya dengan hak mewaris, baca Abdulkadir Muhammad. 1993. Hukum Perdata Indonesia. Bandung: Citra Aditya Bhakti. hlm. 73 . 
UUP memandang perkawinan sebagai ikatan lahir maupun ikatan batin. Ikatan lahir adalah apa yang nampak keluar/formalitas atau hubungan formil. Ikatan lahir mengungkapkan adanya hubungan hukum antara seorang laki-laki dan perempuan sebagai suami isteri, dan nyata dapat dilihat baik bagi dirinya sendiri, orang lain, dan masyarakat. Ikatan lahir tampak dengan dilangsungkannya perkawinan dengan memenuhi syarat-syarat yang ditentukan oleh hukum yang berlaku.

Ikatan batin adalah ikatan yang tidak formil. ${ }^{2}$ Ikatan batin antara suami isteri menampakkan adanya kasih sayang antara suami isteri. Kasih sayang itulah yang menjadi dasar ikatan perkawinan dan akan melanggengkan perkawinan tersebut, menciptakan kerukunan dan menjadi fondasi dalam kehidupan keluarga.

Perkawinan dimaksudkan untuk membentuk keluarga yang bahagia dan kekal berdasarkan Ketuhanan Yang Maha Esa. Menurut J. Prins, titik berat perkawinan dalam UUP adalah pada Pasal 2, yakni pelaksanaan perkawinan secara agamis. Ini adalah salah satu perbedaan dengan KUHPerdata. ${ }^{3}$

\section{b. Pengertian Anak}

Anak adalah insan pribadi yang memiliki dimensi khusus dalam kehidupannya. Tumbuh kembang anak memerlukan bantuan orangtua, tetapi faktor lingkungan juga memiliki peranan yang sangat penting dalam mempengaruhi kepribadian anak dalam menyongsong fase kedewasaannya. ${ }^{4}$ Anak adalah sosok yang akan memikul tanggungjawab di masa yang akan datang, sehingga tidak berlebihan jika negara memberikan suatu perlindungan khusus bagi anak-anak dari perlakuan yang dapat menghancurkan masa depannya.

Dalam pandangan sosiologis, Haditono berpendapat bahwa anak merupakan makhluk yang membutuhkan pemeliharaan, kasih sayang, dan tempat bagi perkembangannya. Anak merupakan bagian dari keluarga, dan keluarga memberi kesempatan bagi anak untuk belajar tingkah laku yang penting untuk perkembangan yang cukup baik dalam kehidupan bersama. Tidak berlebihan kiranya jika anak berhak mendapatkan pemeliharaan, pendidikan dan pendampingan dari kedua orangtuanya. ${ }^{5}$ Hak inilah yang membentuk dan mengisi watak anak, sehingga mereka nantinya dapat menjadi orang-orang yang mampu bersikap dan berlaku benar dan bertanggungjawab.

Mengenai siapa yang dimaksud dengan anak, Pasal 47 ayat (1) UUP memberikan definisi anak adalah mereka yang belum mencapai umur 18 (delapan belas) tahun atau belum pernah melangsungkan perkawinan. Anak berada di bawah kekuasaan orang tuanya selama mereka tidak dicabut dari kekuasaannya.

\footnotetext{
2 K.Wantjik Saleh. 1980. Hukum Perkawinan Indonesia. Cetakan keempat. Jakarta: Ghalia Indonesia. hlm. 15.

3 J. Prins. 1982. Tentang Hukum Perkawinan di Indonesia. Cetakan pertama. Jakarta: Ghalia Indonesia. hlm. 25.

4 D.Y. Witanto. 2012. Hukum Keluarga Hak dan Kewajiban Anak Luar Kawin Pasca Keluarnya Putusan MK tentang Hak Uji Materiil UU Perkawinan. Jakarta: Prestasi Pustaka. hlm. 10. Ibid., hlm. 6.
} 
Konsep anak dalam KUHPerdata berbeda dengan konsep anak dalam UUP. KUHPerdata hanya memberikan pengertian "belum dewasa" atau "minderjarige" dan bukan "anak-anak". Adapun yang dimaksud dengan "belum dewasa" atau "minderjarige" adalah mereka yang belum mencapai umur genap duapuluh satu tahun, dan tidak lebih dahulu telah kawin. ${ }^{6}$ Terhadap mereka yang "belum dewasa", UU menentukan bahwa mereka harus berada di bawah kekuasaan orangtua atau wali.

Bila dibandingkan antara ketentuan anak dalam UUP dan KUHPerdata, maka terdapat persamaan dan perbedaan di antara keduanya. Persamaannya adalah:

a. Konsep "anak" dalam UUP pada dasarnya sama dengan konsep "belum dewasa" atau "minderjarige" dalam KUHPerdata. Mereka adalah seseorang yang belum genap mencapai usia tertentu sebagai batas ukuran kedewasaan.

b. Anak atau mereka yang belum dewasa/minderjarige menurut ketentuan UU harus diletakkan di bawah kekuasaan orangtua.

Adapun perbedaannya adalah bahwa batas usia dewasa menurut Pasal 47 UUP adalah 18 tahun, sedangkan batas usia dewasa menurut Pasal 330 KUHPerdata adalah 21 tahun.

UU yang khusus ditujukan bagi perlindungan anak pun memberikan batas usia anak secara berbeda-beda. UUKA memberikan batasan anak sampai dengan usia 21 (dua puluh satu) tahun dan belum pernah kawin. ${ }^{7}$ UU Perlindungan Aanak 2002 memberikan batas usia anak, mulai dari anak yang masih dalam kandungan ibunya sampai dengan batas usia 18 (delapan belas) tahun.

UU lain yang mengatur tentang batas usia dewasa adalah UUJN. Mengenai batas usia dewasa, UUJN 2014 mengatur dalam Pasal 39 yang menyebutkan:

(1) Penghadap harus memenuhi syarat sebagai berikut: a. paling rendah berumur 18 (delapan belas) tahun atau telah menikah; dan b. cakap melakukan perbuatan hukum.

(2) Penghadap harus dikenal oleh Notaris atau diperkenalkan kepadanya oleh 2 (dua) orang saksi pengenal yang berumur paling rendah 18 (delapan belas) tahun atau telah menikah dan cakap melakukan perbuatan hukum atau diperkenalkan oleh 2 (dua) penghadap lainnya.

Berdasarkan uraian tersebut di atas, nampak adanya perbedaan mengenai siapa yang termasuk dalam kategori anak. Beberapa UU menyebut batas usia anak adalah 18 tahun, sedangkan yang lain menyebutkan batas usia 21 tahun. Mengingat bahwa hukum merupakan satu kesatuan sistem, maka berdasarkan asas hukum lex posteriori derogat legi priori, yang dimaksud dengan "anak" adalah seseorang yang belum berusia 18 tahun, termasuk anak yang masih berada dalam kandungan ibunya.

Dalam struktur masyarakat Indonesia, kehadiran anak merupakan hal yang penting. Dalam sistem UUP Indonesia, tujuan hidup berumah tangga adalah untuk membentuk sebuah keluarga yang bahagia dan kekal berdasarkan Ketuhanan Yang Maha Esa. Ukuran kebahagiaan dalam perkawinan adalah hadirnya anak di tengah-

Baca Pasal 330 ayat (1) KUHPerdata.

Baca Pasal 1 angka 2 UUKA. 
tengah keluarga. Tidak dilahirkannya anak bahkan merupakan alasan untuk melakukan poligami. Pasal 4 ayat (2) huruf c UUP menyebutkan:

Pengadilan dimaksud dalam ayat (1) pasal ini hanya memberi izin kepada suami yang akan beristri lebih dari seorang apabila:

a. istri tidak dapat menjalankan kewajibannya sebagai istri;

b. istri mendapat cacat badan atau penyakit yang tidak dapat disembuhkan;

c. istri tidak dapat melahirkan keturunan.

Dalam kenyataan kehadiran anak tidak selamanya diharapkan. Banyak fakta menunjukkan ada orangtua yang membuang, bahkan membunuh anaknya demi menutupi aib keluarga. Kelahiran si anak akan membuat malu bagi keluarga karena anak itu dihasilkan dari hubungan di luar perkawinan yang tidak dibenarkan oleh ajaran agama dan etika yang berlaku di masyarakat ${ }^{8}$.

Masyarakat juga sistem hukum ${ }^{9}$, membedakan anak menjadi "anak sah" dan "anak luar kawin". Terhadap anak luar kawin, hukum memperlakukan secara berbeda. Anak sah memiliki kedudukan istimewa dengan hak secara penuh. Anak luar kawin memiliki hak yang lebih terbatas. Menurut KUHPerdata, anak sah memiliki hubungan keperdataan dengan kedua orangtuanya, sedangkan anak luar kawin tidak memiliki hubungan keperdataan dengan siapapun. Bahkan ayah biologisnya dan ibu yang melahirkannya perlu melakukan pengakuan terhadap si anak luar kawin, agar hubungan keperdataan dengan anaknya terbentuk. Berbeda dengan KUHPerdata, UUP mengambil sikap bahwa anak luar kawin memiliki hubungan keperdataan dengan ibunya dan keluarga ibunya.

\section{c. Perlakuan terhadap Anak Luar Kawin}

Anak luar kawin mengalami perbedaan status dan perlakuan oleh hukum.

Dalam UUP, anak luar kawin memiliki hubungan keperdataan dengan ibunya dan keluarga ibunya. Dalam perkembangannya, Mahkamah Konstitusi berdasarkan permohonan peninjauan terhadap Pasal 43 jo Pasal 2 ayat (1) UUPmemberikan putusan Nomor 46/PUU-VIII/2010, sehingga Pasal 43 ayat (1) UUP harus dibaca:

"Anak yang dilahirkan di luar perkawinan mempunyai hubungan perdata dengan ibunya dan keluarga ibunya serta dengan laki-laki sebagai ayahnya yang dapat dibuktikan berdasarkan ilmu pengetahuan dan teknologi dan/atau alat bukti lain menurut hukum mempunyai hubungan darah, termasuk hubungan perdata dengan keluarga ayahnya". ${ }^{10}$

Dalam sistem KUHPerdata, anak sah memiliki hak penuh untuk mendapatkan pemeliharaan, pendidikan dan hak waris. Tetapi anak luar kawin, tidak mendapatkan hak apapun. Anak luar kawin seperti halnya anak yang tak berbapak tak beribu.

Menurut Ko Tjai Sing, pada masa lalu, hubungan perkawinan sangat disakralkan, sehingga hubungan-hubungan antara laki-laki dengan perempuan di

$8 \quad$ D.Y. Witanto. 2012. op.cit. hlm. 3.

9 KUHPerdata, UU Nomor 1 tahun 1974 tentang Perkawinan, Hukum Islam dan hukum Adat mengenal pembedaan anak menjadi "anak sah" dan "anak luar kawin".

10 Berdasarkan Keputusan Mahkamah Konstitusi Nomor 46/PUU-VIII/2010. 
luar ikatan perkawinan yang sah menurut ukuran masyarakat setempat dipandang rendah. Pembedaan ini karena pada dasarnya pembentuk undang-undang tidak ingin anak-anak ditumbuhkan dan dilahirkan di luar perkawinan. ${ }^{11}$ Untuk mencapai itu pembentuk undang-undang mengadakan pembedaan antara anak-anak yang sah dan anak-anak yang tidak sah. Anak-anak yang tidak sah diberikan kedudukan hukum yang buruk sekali dan akibat-akibat kesalahan ayah dan ibu dibebankan pada anak-anak yang tidak bersalah. ${ }^{12}$

\section{d. Disharmoni dalam Perlindungan Anak Luar Kawin di Indonesia}

Praktek pembedaan perlakuan terhadap anak luar kawin terus terjadi. Sistem KUHPerdata mengatur lembaga "pengakuan anak" serta lembaga "pengesahan anak luar kawin" sebagai lembaga untuk mendapatkan hubungan keperdataan dengan orangtua biologisnya. UUP tidak mengatur sama sekali kedua lembaga tersebut. Mengingat ketiadaan norma hukum yang mengatur lembaga pengakuan anak serta lembaga pengesahan anak luar kawin, maka di dalam praktek mengacu pada KUHPerdata.

Pengaturan lembaga pengakuan anak serta lembaga pengesahan anak baru ada pada tahun 2006 yakni dengan diundangkannya UU Nomor 23 Tahun 2006 tentang Administrasi dan Kependudukan (UU Adminduk 2006). Dengan diundangkannya UU Nomor 24 Tahun 2013 tentang Perubahan UU Adminduk 2006, maka beberapa ketentuan dalam UU Adminduk 2006 direvisi.

Salah satu revisi yang paling berdampak terhadap status anak luar kawin adalah revisi terhadap Pasal 49 dan Pasal 50 UU Adminduk 2006. Adapun revisinya berkaitan dengan ketentuan bahwa hanya anak luar kawin yang lahir dari perkawinan siri saja yang dapat diakui dan/atau disahkan. Ini berarti bahwa anak luar kawin yang kedua orangtuanya belum/tidak menikah secara siri kehilangan hak untuk diakui dan/atau disahkan. Ketentuan menyebabkan terjadinya saling pertentangan (disharmoni) antar norma yang mengatur hak keperdataan anak luar kawin, karena menurut ketentuan dalam KUHPerdata yang selama ini digunakan sebagai acuan di Pengadilan Negeri dan Kantor Dinas Kependudukan dan Pencatatan Sipil (Dispendukcapil), setiap anak luar kawin pada dasarnya dapat diakui dan/atau disahkan sekalipun kedua orangtua biologisnya tidak menikah satu sama lain. Revisi UU Adminduk 2013 justru menimbulkan diskriminasi terhadap anak luar kawin.

Hak anak adalah hak asasi manusia. Oleh karena itu, setiap anak berhak menikmati hak atas pemeliharaan dan hak atas pendidikan. Hal ini mengacu kepada CRC (Convention on the Rights of the Child) sebagaimana telah diratifikasi oleh Negara Indonesia dalam Keputusan Presiden Republik Indonesia Nomor 36 Tahun 1990. Disharmoni ini karena menyebabkan ketidakjelasan hukum yang potensial merugikan anak luar kawin, oleh karena itu perlu dilakukan harmonisasi norma hukumnya sehingga lebih menjamin keadilan, kemanfaatan, serta kepastian hukum.

Ko Tjai Sing. op.cit. hlm. 403.

Ibid. Sebagai catatan, Ko Tjai Sing memakai istilah "anak sah" dan "anak tidak sah". 


\section{Metode Penelitian}

Penelitian ini merupakan penelitian yuridis normatif dengan data primer dan sekunder, yang berupa:

a. Inventarisasi norma hukum positif yang yang mengatur tentang hak keperdataan anak dan perlindungan anak.

b. Karya tulis dan pemikiran para ahli hukum.

c. Pandangan dari para pakar, terutama berkaitan dengan praktek revisi perundangundangan, dengan narasumber: (1) BPHN (Jakarta); (2) DPR RI (Jakarta); dan (3) Narasumber hukum adat dari Minahasa Utara

Analisa data dilakukan dengan analisis kualitatif.

\section{Hasil Penelitian dan Pembahasan}

\section{a. Norma-norma Hukum Eksisting yang Memberikan Perlindungan Hukum bagi Anak Luar Kawin di Indonesia}

Anak adalah subjek hukum. Meskipun belum cukup umur, anak bukanlah manusia dalam bentuknya yang mini. Anak tetaplah subjek hukum yang memerlukan perlindungan, karena anak tidak mampu/belum mampu melindungi dirinya sendiri. Anak senantiasa memerlukan perlindungan dari orang/pihak lain, baik orangtua, wali, pengampu, masyarakat, dan negara. Negara dibutuhkan peran sertanya untuk menetapkan regulasi untuk melindungi anak. Kebijakan perlindungan oleh negara akan menjadi alur penting dalam menetapkan langkahlangkah selanjutnya.

Konstitusi negara menjadi sumber dari segala hak yang dimiliki setiap warga negara. ${ }^{13}$ UUD1945 sebagai konstitusi negara, merupakan dasar hukum tertinggi bagi tatanan kehidupan kenegaraan. UUD1945 mencantumkan pula tujuan pembentukan negara, yakni dalam Alinea IV UUD 1945 yang menyebutkan:

a) Membentuk Pemerintah negara Indonesia yang melindungi segenap bangsa Indonesia dan seluruh tumpah darah Indonesia;

b) Memajukan kesejahteraan umum;

c) Mencerdaskan kehidupan bangsa; dan

d) Ikut melaksanakan ketertiban dunia yang berdasarkan kemerdekaan, perdamaian abadi, dan keadilan sosial.

Tujuan negara untuk melindungi segenap bangsa Indonesia, tanpa membedakan orang dari segi suku, ras, dan agama. Artinya, bahwa setiap warga negara Indonesia diperlakukan sama di hadapan hukum dan pemerintahan. Perlindungan ini juga tidak membedakan apakah seseorang termasuk anak sah ataukah ALK. Dalam ilmu hukum hal ini dikenal sebagai asas "equality before the law". Adapun pasal-pasal dalam UUD1945 yang memberikan perlindungan bagi hak anak adalah sebagai berikut:

13 Muhamad Erwin. 2015. Filsafat Hukum, Refleksi Kritis terhadap Hukum dan Hukum Indonesia dalam Dimensi Ide dan Aplikasi. Edisi Revisi. Jakarta: PT. Rajagrafindo Perkasa. hlm. 319. 
a) Pasal 1 ayat (3) UUD1945 yang menyebutkan bahwa: "Negara Indonesia adalah negara hukum". Pernyataan bahwa negara Indonesia adalah negara hukum membawa konsekuensi negara wajib mewujudkan kesejahteraan bagi rakyat.

b) Pasal 28B UUD1945 yang menyebutkan:

(1) Setiap orang berhak membentuk keluarga dan melanjutkan keturunan melalui perkawinan yang sah.

(2) Setiap anak berhak atas kelangsungan hidup, tumbuh dan berkembang serta berhak atas perlindungan dari kekerasan dan diskriminasi.

c) Pasal 28 D ayat (1) UUD1945 yang menyebutkan: "Setiap orang berhak atas pengakuan, jaminan, perlindungan dan kepastian hukum yang adil serta perlakuan sama di hadapan hukum."

d) Pasal 28D ayat (4) UUD1945 yang menyebutkan: "Setiap orang berhak atas status kewarganegaraan."

e) Pasal 28H ayat (1) UUD1945 yang menyebutkan: "Setiap orang berhak hidup sejahtera lahir dan batin.... "“

Perlindungan sebagaimana ditentukan dalam pasal-pasal tersebut di atas tidak secara khusus dimaksudkan untuk memberikan perlindungan terhadap hak-hak anak pada umumnya, maupun hak anak luar kawin pada khususnya, tetapi merupakan bentuk perlindungan yang umum berlaku bagi setiap warga negara. Sebagai negara kesejahteraan, negara wajib mewujudkan perlindungan hukum bagi setiap orang, termasuk bagi anak-anak serta ALK yang rentan mengalami diskriminasi serta kekerasan.

Ketentuan perlindungan sebagaimana diatur dalam UUD1945 tersebut di atas, ini diatur lebih lanjut dalam berbagai UU sebagai berikut:

a) UU Nomor 1 Tahun 1974 tentang Perkawinan.

b) KUHPerdata.

c) UU Nomor 4 Tahun 1979 tentang Kesejahteraan Anak.

d) UU Nomor 39 Tahun 1999 tentang Hak Asasi Manusia.

e) UU Nomor 23 Tahun 2002 tentang Perlindungan Anak.

f) UU Nomor 23Tahun 2006 tentang Administrasi dan Kependudukan.

g) UU Nomor 24 Tahun 2013 tentang Perubahan atas UU Nomor 23Tahun 2006 tentang Administrasi dan Kependudukan.

h) Keputusan Presiden Nomo 36 Tahun 1990 tentang Pengesahan Konvensi HakHak Anak.

\section{b. Harmonisasi Norma-norma hukum untuk Memberikan Perlindungan Hukum terhadap ALK}

Meskipun undang-undang sebagaimana tersebut di atas bermaksud memberikan perlindungan terhadap hak-hak anak pada umumnya dan perlindungan hak ALK pada khususnya, namun ternyata tujuan tersebut tidaklah selalu selaras antar norma hukum yang satu dengan norma hukum yang lain, yang dapat diuraikan sebagai berikut:

1) UUP mengatur tentang ALK secara singkat, karena hanya diatur dalam satu pasal, yakni Pasal 43 yang menyebutkan: 
(1) Anak yang dilahirkan di luar perkawinan hanya mempunyai hubungan perdata dengan ibunya dan keluarga ibunya.

(2) Kedudukan anak tersebut ayat (1) di atas selanjutnya akan diatur dalam Peraturan Pemerintah.

Namun sampai saat ini, PP sebagaimana termaksud dalam Pasal 43 ayat (2) UUP belum diterbitkan. UUP tidak mengatur tentang lembaga-lembaga penolong yang memberikan perlindungan terhadap hak keperdataan ALK. Ketiadaan dasar hukum menyebabkan praktek pencatatan sipil menggunakan KUHPerdata sebagai pedoman.

2) KUHPerdata mengatur secara lengkap tentang anak luar kawin, termasuk mengatur tentang lembaga pengakuan anak dan lembaga pengesahan anak luar kawin. Kedua lembaga ini memberikan perlindungan terhadap ALK dengan membentuk hubungan hukum antara anak luar kawin dengan ibu dan/atau ayah biologisnya. ${ }^{14}$ Dalam konsep KUHPerdata, ALK tidak memiliki hubungan keperdataan dengan siapapun, bahkan ayah dan/atau ibunya masih harus melakukan pengakuan terhadap anak biologisnya agar timbul hubungan hukum dengannya. Bila ayah dan ibu biologis menikah satu sama lain, maka ALK yang lahir sebelum perkawinan secara sah dapat diakui dan kemudian disahkan. Dengan pengesahan terhadap ALK, maka berlaku konsekuensi hukum, yakni ALK tersebut akan memiliki kedudukan yang sama seperti halnya anak sah. Kedua lembaga tersebut, meskipun tidak diatur dalam UUP, namun dalam praktek dapat dilakukan oleh orang-orang Indonesia asli meskipun KUHPerdata sebetulnya tidaklah dimaksudkan berlaku bagi mereka. ${ }^{15}$ Hal ini dilakukan agar tidak terjadi kekosongan hukum dalam soal pengakuan anak dan pengesahan ALK.

3) Pengaturan tentang ALK dalam undang-undang produk Indonesia baru ada/diundangkan pada tahun 2006, yakni dengan diundangkan Undang-Undang No 23 Tahun 2006 tentang Administrasi Kependudukan (UU Adminduk 2006). Undang-undang ini pada dasarnya merupakan peraturan tentang tata cara pencatatan peristiwa-peristiwa penting dalam kehidupan perseorangan tertentu, dan dimaksudkan sebagai data base kependudukan Indonesia.

\section{c. Hukum Adat sebagai Inspirasi}

Di dalam hukum Adat baik dahulu maupun sekarang orang mengenal lembagalembaga yang bermaksud melepaskan ibu dan anaknya dari nasib malang itu. Imam Sudiyat ${ }^{16}$ menyebutkan dua upaya yang dilakukan masyarakat, yakni:

1. Kawin paksa; dan

2. Kawin darurat.

14 Dalam sistem KUHPerdata, anak luar kawin tidak memiliki hubungan perdata dengan siapapun. Hubungan keperdataan terbentuk dengan dilakukannya pengakuan anak oleh ayah dan/atau ibu biologisnya atau dengan pernikahan ayah dan ibu biologis, maka anak luar kawin dapat disahkan oleh orangtuanya.

15 Berdasarkan wawancara dengan petugas Kantor Dispendukcapil Kota Semarang, Agustus 2016.

16 Iman Sudiyat. 1981. Hukum Adat, Sketsa Asas. Cetakan Kedua. Yogyakarta: Liberty. hlm. 91-92. 
Kedua cara tersebut di atas merupakan upaya yang dilakukan oleh masyarakat untuk menghindari kelahiran anak di luar perkawinan. Kelahiran ALK, selain merupakan aib bagi masyarakat juga dikhawatirkan dapat membuat masyarakat celaka karena anak dilahirkan tanpa upacara-upacara yang mendahului.

Di Minahasa, hubungan antara seorang anak luar kawin dengan lelaki tak kawin yang menurunkannya (ayah biologisnya), sama seperti hubungan anak dengan ayah-(yuridis) nya. Bilamana si ayah menghendaki supaya hubungan itu tak diragukan lagi, maka ia memberikan hadiah (biasanya berupa tanah) yang disebut "lilikur" bagi ibu si anak. Di tempat-tempat lain, anak yang terlahir di luar perkawinan menurut hukum adat anak-anak ini dianggap tidak berayah. Di Ambon, anak-anak Bumiputera Kristen dapat disahkan pada waktu perkawinan orang tuanya. ${ }^{17}$ Ini bukti bahwa hukum Adat Minahasa dan Ambon yang patrilineal memberikan kedudukan dan perlindungan hukum yang baik terhadap anak luar kawin.

\section{d. Pemikiran Hukum sebagai Solusi}

Terdapat beberapa pemikiran berdasarkan idealisme untuk memberikan perlindunagn terhadap hak keperdataan ALK adalah:

(1) Dilakukan revisi atas ketentuan Pasal I butir 10 dan 11, khususnya berkaitan dengan syarat ALK lahir yang dapat diakui (Pasal I butir 10) dan disahkan setelah perkawinan sah ayah ibu biologisnya (Pasal I butir 11) adalah anak-anak yang lahir dalam perkawian secara agama. Ketentuan UU Adminduk 2006 jauh lebih mengakomodir kepentingan perlindungan hak keperdataan ALK. Hal ini dengan pertimbangan tidak setiap ALK lahir dalam hubungan perkawinan menurut hukum agama.

(2) UUP perlu mengatur tentang status dan kedudukan ALK, terutama setelah adanya Putusan MK No. 046/PUU-VIII/2010, serta beberapa persoalan lain seperti batas usia kawin.

(3) Mengadopsi kearifan lokal dalam masyarakat adat, yang terbukti mampu memberikan perlindungan hak-hak ALK.

\section{Kesimpulan dan Saran} berikut:

Berdasarkan uraian pada bab di atas dapat disimpulkan hal-hal sebagai

a) Dalam sistem tata hukum Indonesia terdapat beberapa norma yang memberikan perlindungan terhadap hak keperdataan ALK. UUD1945 memberikan perlindungan dalam Alinea IV Pembukaan, Pasal 1 ayat (3), Pasal 28B ayat (1) dan ayat (2), Pasal 28D ayat (1) dan ayat (4), dan Pasal 28H ayat (1) UUD1945. Pasal-pasal tersebut menjadi landasan hukum pengaturan dalam berbagai UU lain sebagai peraturan pelaksanaannya, yakni: UUP, KUHPerdata, UUKA, UUHAM, UU Perlindungan Anak jo UU Nomor 35 Tahun 2014, UU Administrasi dan Kependudukan jo UU

Ter Haar, B. Bzn. 1960. Asas-Asas dan Susunan Hukum Adat, Terjemahan K. Ng. Soebakti Poesponoto. Jakarta: Pradnja Paramita. hlm. 95, Iman Sudiyat, loc.cit. 
Nomor 24 Tahun 2013, Keppres Nomor 36 Tahun 1990 tentang Pengesahan Convention of the Right of the Child (Konvensi Hak-Hak Anak). Norma-norma eksisting tersebut memberikan perlindungan terhadap anak, termasuk ALK.

b) Terdapat disharsmoni antar norma, karena dengan diundangkannya UU No. 24 Tahun 2013 ALK justru kehilangan hak untuk diakui dan disahkan, karena hanya ALK yang lahir dalam perkawinan menurut hukum agama sajalah yang dapat diakui dan disahkan.

c) Kearifan lokal yang berasal dari ketentuan hukum adat dapat digali untuk memberikan perlindungan bagi ALK.

\section{Ucapan Terimakasih}

Penelitian ini didanai dengan Dana Riset skim Penelitian Disertasi Doktor Kementerian Riset dan Teknologi Republik Indonesia tahun 2017. Penulis menyampaikan terimakasih yang tak terhingga atas pemberian dana Riset skim PDD.

\section{Daftar Pustaka}

Abdulkadir Muhammad. 1993. Hukum Perdata Indonesia. Bandung: Citra Aditya Bhakti.

D.Y. Witanto. 2012. Hukum Keluarga, Hak dan Kedudukan Anak Luar Kawin Pasca Keluarnya Putusan MK tentang Uji Materiil UU Perkawinan. Jakarta: Prestasi Pustaka.

Hilman Hadikusuma. 2003. Hukum Perkawinan Adat dengan Adat Istiadat dan Upacara Adatnya. Cetakan keempat. Bandung: Citra Aditya Bakti.

Iman Sudiyat. 1981. Hukum Adat, Sketsa Asas. Cetakan Kedua. Yogyakarta: Liberty.

J. Prins. 1982. Tentang Hukum Perkawinan di Indonesia. Cetakan pertama. Jakarta: Ghalia Indonesia.

J. Satrio. 2000. Hukum Keluarga tentang Kedudukan Anak dalam Undang-Undang. Cetakan pertama. Bandung: Citra Aditya Bakti.

Ko Tjai Sing, 1960, Hukum Perdata Jilid I Hukum Keluarga (Diktat Lengkap), Semarang: Etikad Baik.

Muhamad Erwin. 2015. Filsafat Hukum, Refleksi Kritis terhadap Hukum dan Hukum Indonesia dalam Dimensi Ide dan Aplikasi. Edisi Revisi. Jakarta: PT. Rajagrafindo Perkasa.

Neng Djubaidah. 2012. Pencatatan Perkawinan dan Perkawinan Tidak Dicatat, Menurut Hukum Tertulis di Indonesia dan Hukum Islam. Cetakan kedua. Jakarta: Sinar Grafika.

Ter Haar. 1960. Asas-Asas dan Susunan Hukum Adat, Terjemahan K. Ng. Soebakti Poesponoto. Jakarta: Pradnja Paramita.

Wantjik Saleh K. 1980. Hukum Perkawinan Indonesia. Cetakan keempat. Jakarta: Ghalia Indonesia. 


\section{Perundang-undangan:}

Undang-Undang Dasar Negara Republik Indonesia 1945.

Kitab Undang-Undang Hukum Perdata.

UU Nomor 1 Tahun 1974 tentang Perkawinan.

UU Nomor 4 Tahun 1979 tentang Kesejahteraan Anak.

UU Nomor 39 Tahun 1999 tentang Hak Asasi Manusia.

UU Nomor 23 Tahun 2002 tentang Perlindungan Anak.

UU Nomor 23 Tahun 2006 tentang Administrasi dan Kependudukan.

UU Nomor 24 Tahun 2013 tentang Perubahan Undang-Undang Nomor 23 Tahun 2006 tentang Administrasi dan Kependudukan.

UU Nomor 35 Tahun 2014 tentang Perubahan Undang-Undang Nomor 23 Tahun 2003 tentang Perlindungan Anak.

Keppres Nomor 36 Tahun 1990 tentang Pengesahan Convention on the Rights of the Child (Konvensi tentang Hak-Hak Anak).

\section{Internet:}

http://warta17agustus.com/berita-disertasi-i-nyoman-sujana-shmhum-sorotikedudukan-hukum-anak-luar-kawin-dalam-perspektif-putusan-mahkamahkonstitusi-nomor-46puuvii2010.html, diunduh 15 Juli 2015.

http://www.ui.ac.id/berita/kartini-dan-hak-asasi-manusia.html, diunduh tanggal 21 Januari 2017.

http://bunga-legal.blogspot.co.id/2010/05/sejarah-pemikiran-ham-diindonesia.html, diunduh tanggal 21 Januari 2017.

http://www.zonasiswa.com/2014/07/sejarah-hak-asasi-manusia-ham.html, diunduh pada tanggal 18 Januari 2017. 